\title{
Structure-Activity Relationship (SAR) Studies on Oxazolidinone Antibacterial Agents. 1. Conversion of 5-Substituent on Oxazolidinone
}

\author{
Ryukou Tokuyama, * Yoshiei Takahashi, Yayoi Tomita, Tomio Suzuki, Toshihiko Yoshida, \\ Nobuhiko IwASAKI, Noriyuki Kado, Eiichi OKEZAKI, and Osamu Nagata \\ Research and Development Division, Hokuriku Seiyaku Co., Ltd., 37-1-1, Inokuchi, Katsuyama, Fukui, 911-8555, Japan. \\ Received July 21, 2000; accepted December 22, 2000
}

\begin{abstract}
A structure-activity relationship (SAR) study on 5-substituted oxazolidinones as an antibacterial agent is described. The oxazolidinones, of which 5-acetylaminomethyl moiety was converted into other functions, were prepared and evaluated for antibacterial activity. Elongation of the methylene chain (8) and conversion of the acetamido moiety into guanidino moiety (12) decreased the antibacterial activity. The replacement of carbonyl oxygen $(=0)$ by thiocarbonyl sulfur $(=S)$ enhanced in vitro antibacterial activity. Especially, compound 16, which had the 5-thiourea group, showed $4-8$ stronger in vitro activity than linezolid. Our SAR study revealed that the antibacterial activity was greatly affected by the conversion of 5 -substituent.
\end{abstract}

Key words oxazolidinone; antibacterial activity; 5-substituted oxazolidinone; structure-activity relationship

Several antibiotics have been widely prescribed and found to be greatly effective on various infectious disorders in recent years. The emergence of multi-drug-resistant grampositive bacteria, however, has become a significant problem. In particular, methicillin-resistant Staphylococcus aureus (MRSA) and vancomycin-resistant enterococci (VRE) are becoming imminent pathogens in clinical.

The oxazolidinones, exemplified by Dup-721 (1), ${ }^{1)}$ are an exciting new class of synthetic antibacterial agents and are reported to be effective against staphylococci, streptococci and enterococci. ${ }^{2)}$ Dup-721 has been found to effectively inhibit the protein synthesis in the initial stage. ${ }^{3)}$ Because of their unique mode of action, the oxazolidinones are thought to exhibit antibacterial activity without evidence of cross-resistance to any known antibiotics. However, Dupont's group was forced to discontinue the development of Dup-721 due to its severe toxicity. Pharmacia group then started a program to ameliorate the properties of Dup-721 and were successful in discovering PNU-100480 (2) ${ }^{4)}$ and linezolid (3). ${ }^{5)}$ Linezolid is effective against numerous serious Gram-positive human pathogens caused by MRSA and VRE without severe toxicity. It has been shown to selectively bind to the $50 \mathrm{~S}$ ribosomal subunit and to inhibit bacterial translation at the initial phase of protein synthesis. ${ }^{\text {) }}$

Concerning the 5-substituent on the oxazolidinone ring, Dupont's group reported that the 5-hydroxymethyl or the 5halogenomethyl group had weak antibacterial activities against gram-positive bacterial strains. ${ }^{7)}$ Furthermore, Gregory et $a l^{1}{ }^{1}$ concluded that the acetylaminomethyl moiety was the best substituent at the 5-position on oxazolidinone, in consequence of their SAR study. But their effort was mainly limited to carbonyl functionalities. So we set about to convert the 5-substituent on the oxazolidinone into other functionalities such as thiocarbonyl groups, in order to determine the effect of the 5-substituent on antibacterial activity and to find a promising oxazolidinone antibacterial agent with excellent antibacterial activities against MRSA and VRE.

The introduction of thiocarbonyl functionalities, however, was reported by Bayer and Pharmacia groups simultaneously. ${ }^{8)}$ The two groups revealed that some 5-thiocarbonyl- functionalized oxazolidinones exhibited excellent activities at the same time that we synthesized a series of oxazolidinones with these functionalities.

In this paper, we describe our extensive SAR study on various 5-substituents of oxazolidinone for antibacterial activity.

Chemistry Elongated compound $\mathbf{8}$ was synthesized as shown in Chart 2. Conversion of compound $\mathbf{4}$ to oxazolidinone 6 was accomplished by use of $n$-BuLi and $(S)-3,4-$ epoxybutenyl propionate (5). The alcohol 6 was reacted with methanesulfonyl chloride, followed by a treatment of sodium azide to yield compound 7. Hydrogenation of the azide 7 and following acetylation gave the desired compound $\mathbf{8}$.

5-Guanidine 12 and 5-thiocarbonyl compounds (13-21) were prepared as shown in Chart 3. The guanidine 12 was synthesized from $\mathbf{1 0}^{4)}$ with $1 H$-pyrazole-1-carboxamidine. Thioamide derivatives $(\mathbf{1 3}-\mathbf{1 5})$ were efficiently obtained by treatment of the reference compounds $(\mathbf{2}, \mathbf{2 2}, \mathbf{2 3})$ with Lawesson's reagent. Thiourea derivatives $(\mathbf{1 6}, \mathbf{1 9})$ were obtained from isothiocyanate $\mathbf{1 1}$, which was easily derived from key intermediate $\mathbf{1 0}$ with carbon disulfide and ethyl chloroformate. The other thiourea derivatives $(\mathbf{1 7}, \mathbf{1 8})$ were synthesized by treatment of compound $\mathbf{1 0}$ with various alkylisothiocyanate reagents. Thiosemicarbazide derivative (20) was syn-

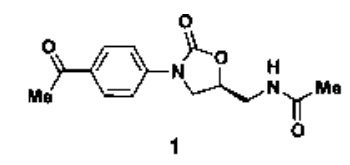

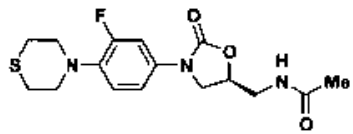

PNU-100480 [2]

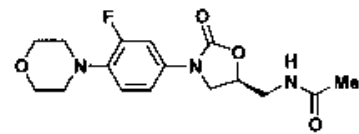

Linezolid (3)

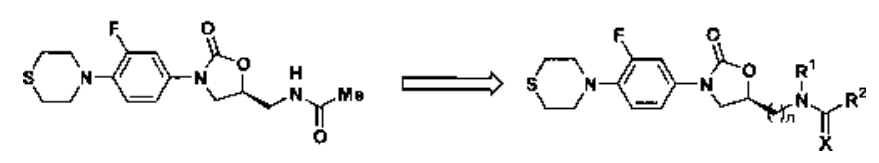

Chart 1 

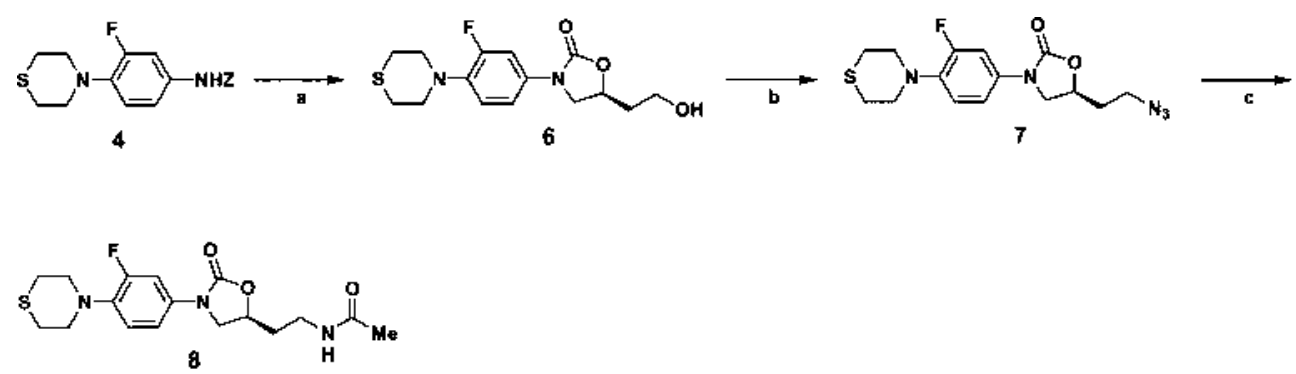

a) n-BuLi, (S)-3,4-Epoxybutenyl propionate 5 b) 1) $\mathrm{MSCl}$ 2) NaN $\mathrm{N}_{3}$ c) 1) $\mathrm{Ph}_{3} \mathrm{P}, \mathrm{H}_{2} \mathrm{O}$ 2) $\mathrm{Ac}_{2} \mathrm{O}$

Chart 2
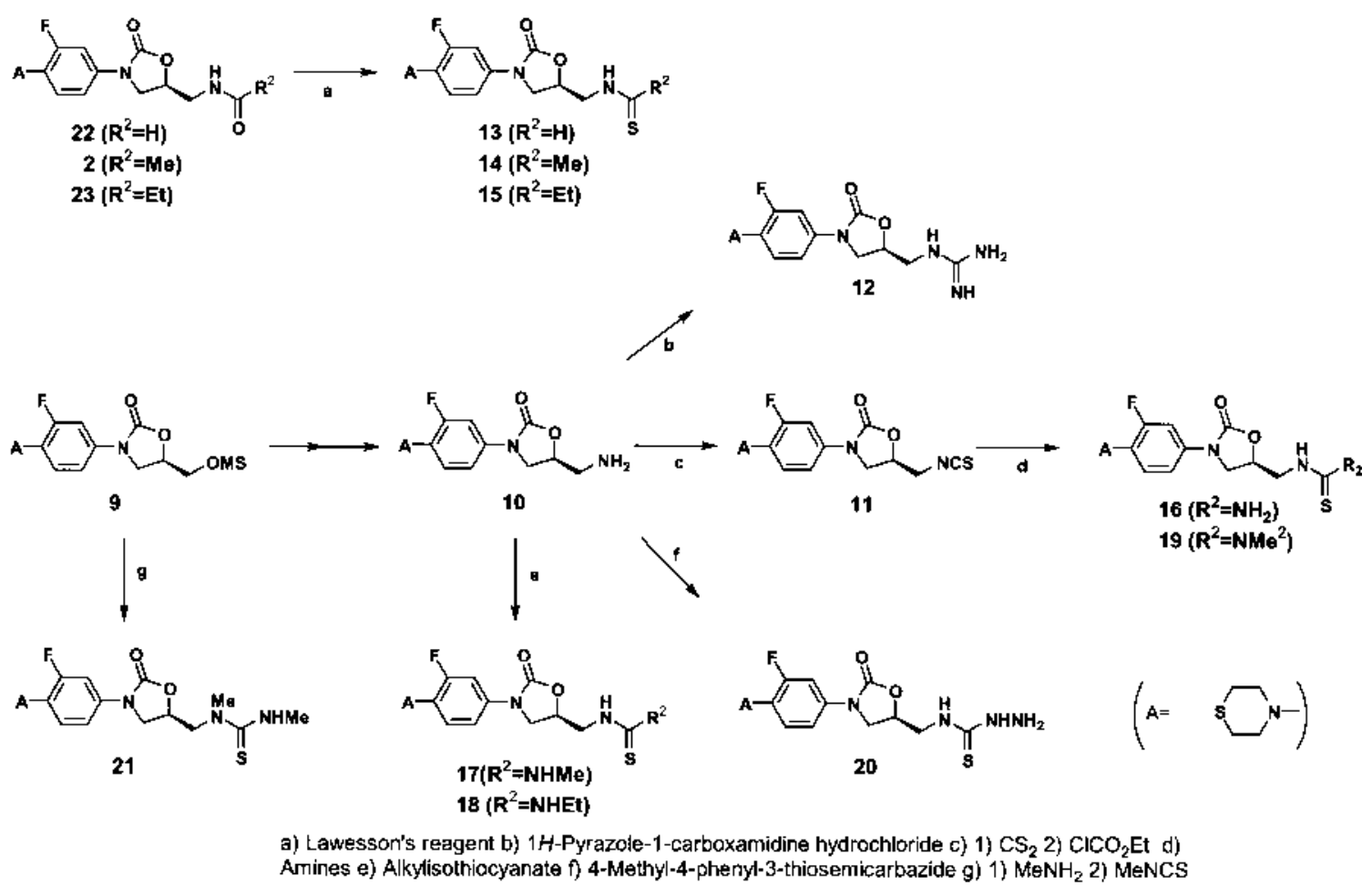

Chart 3

thesized from 10 with 4-methyl-4-phenyl-3-thiosemicarbazide. Regarding $N, N^{\prime}$-dimethylthiourea derivative (21), the substitution of methanesulfonyl group (9) with methylamine followed by the reaction with methylisothiocyanate reagent gave the desired compound. The physicochemical data of these compounds are listed in the experimental section.

\section{Results and Discussion}

All of the oxazolidinone derivatives were tested for antibacterial activity against both standard (Staphylococcus aureus $\mathrm{SMITH})$ and clinically isolated strains $[S$. aureus HPC1360 (MRSA), S. aureus HPC428 (MRSA), Enterococcus faecium HPC1322 and E. casseliflavus HPC1310 (VRE)]. Their minimum inhibitory concentrations (MICs $\mu \mathrm{g} / \mathrm{ml}$ ) are shown in Table 1 . Linezolid (3) and vancomycin were used as reference compounds.

The elongated compound $\mathbf{8}$ showed no antibacterial activity. This result suggested that the length of methylene $(n)$ at 5 -position would greatly influence the activity and that suit- able length for the activity would be $n=1$. We next replaced the carbonyl oxygen $(=\mathrm{O})$ by imino nitrogen $(=\mathrm{NH})$ or thiocarbonyl sulfur $(=\mathrm{S})$ and investigated their influence on the antibacterial activity. The guanidine compound $\mathbf{1 2}$ was inactive while the corresponding urea compound $\mathbf{2 4}$ showed moderate activity. The guanidino moiety exists in equilibrium with three conjugated bases since proton dissociation can occur from each of the three nitrogen atoms; it is normally considered to exist as a charged monocationic species under any physiological conditions that might be envisaged. We assumed that these characteristics of guanidino moiety might reduce the activity. On the other hand, the replacement of carbonyl oxygen $(=\mathrm{O})$ by thiocarbonyl sulfur $(=\mathrm{S})(13 v s$. 22, 15 vs. 23, 16 vs. 24) enhanced antibacterial activity. Especially, the activity of thiourea derivative 16 was $2-4$ times stronger than that of the corresponding urea compound $\mathbf{2 4}$. Moreover, the activity of compound 16 was 4-8 times stronger than that of linezolid (3). The introduction of methyl (17), ethyl (18) and dimethyl (19) groups at the terminal ni- 
Table 1. In Vitro Antibacterial Activities and Hydrophobic Parameter of 5-Substituted Oxazolidinones

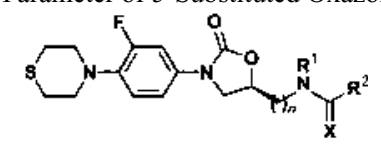

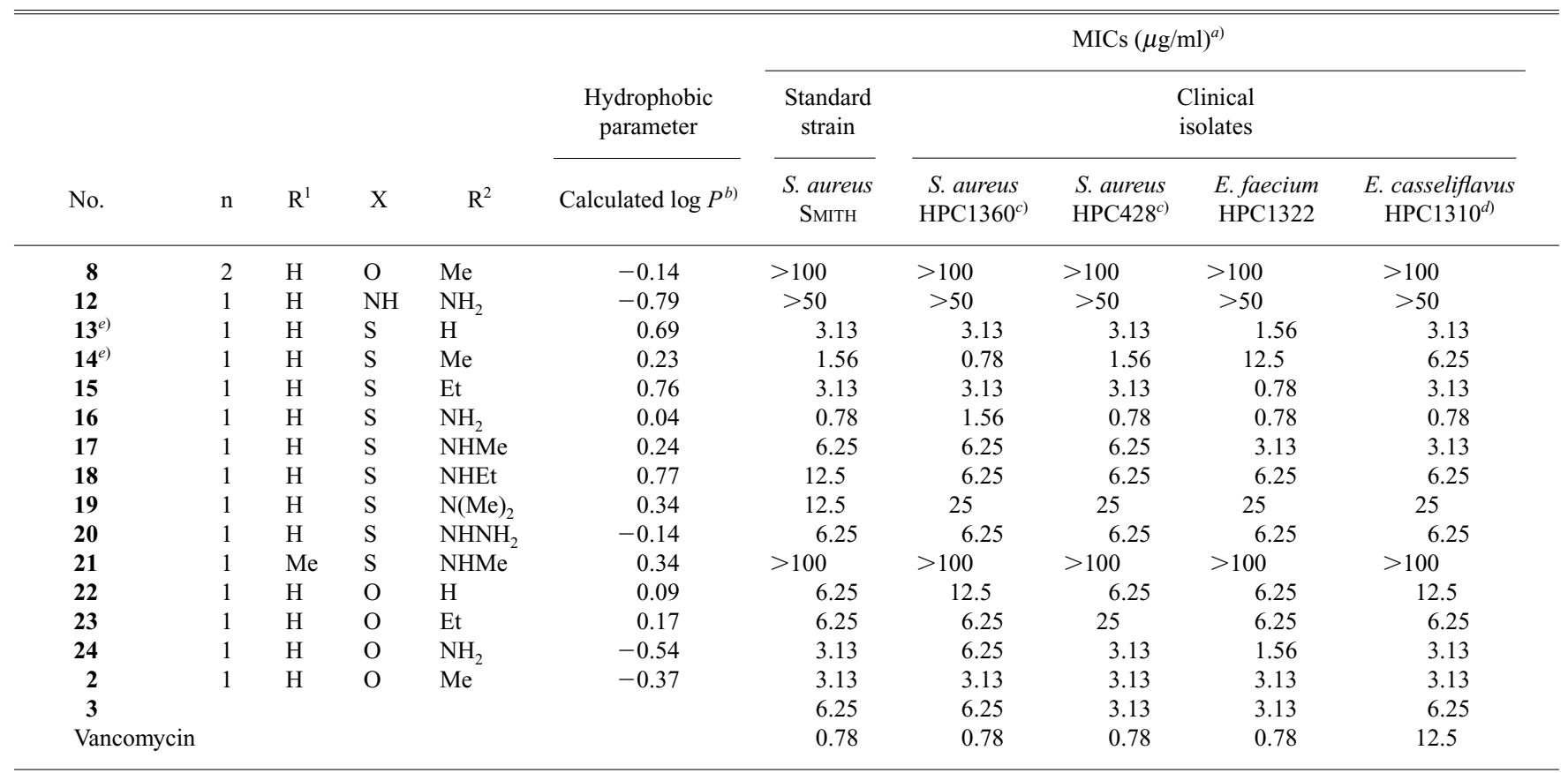

a) Inoculum size, one loopful of $10^{6} \mathrm{CFU} / \mathrm{ml} . \quad$ b) Ref. 9). c) MRSA. d) VRE. e) Ref. 10).

trogen atom, however, led to remarkably decreased antibacterial activities. Partition coefficient $(\log P)$, which is well used as an index of lipophilicity, is one of the important physicochemical parameters. We were interested in their lipophilicities since the introduction of alkyl groups induced the increase of lipophilicity. However, thiosemicarbazide compound $\mathbf{2 0}$ also decreased antibacterial activity in spite of its hydrophilicity (-0.14). Additionally, compound $\mathbf{2 0}$ had antibacterial activity similar to compounds $\mathbf{1 7}$ and $\mathbf{1 8}$, though they had quite different calculated $\log P$ values. Thus, the variety of antibacterial activity by introduction of the substituent at the terminal nitrogen atom seems to be caused by other factors, such as bulkiness of the substituent, rather than by the variety of lipophilicity.

We next investigated the effect of hydrogen atom $\left(\mathrm{R}^{1}\right)$ at the proximal nitrogen atom. Methylation at the proximal nitrogen atom, as demonstrated for compound $\mathbf{2 1}$, was inactive. Therefore, the hydrogen atom at this position is essential for antibacterial activity in 5-thiocarbonyl oxazolidinone. Denis and Seneci ${ }^{11)}$ reported that the oxygen atom at 1 -position on oxazolidinone ring was indispensable for the appearance of antibacterial activity. And some reports referred to the presence of an internal hydrogen bond as an active conformation in [2-(4-piperidinyl)ethyl]thiourea or phenethylthiazolethiourea compounds. ${ }^{12)}$ We therefore assumed that pseudo intramolecular hydrogen bonding between NH moiety at the 5-position and oxygen atom on the oxazolidinone ring could be formed and be considered to act as an active conformation. However, the existence of intramolecular hydrogen bonding was not observed in our ${ }^{1} \mathrm{H}-\mathrm{NMR}$ studies by comparison with corresponding pyrrolidone derivatives that could not form the internal hydrogen bond with $\mathrm{NH}$ moiety at 5 -position. The $\mathrm{NH}$ moiety is probably essential as the binding site in 5-thiocarbonyl oxazolidinones.

In conclusion, we synthesized some oxazolidinones in order to investigate the effect of the 5-substituent for antibacterial activity. It was proved that the antibacterial activity was greatly affected by conversion of the 5 -substituent, as a consequence of our effort. Among them, 5-thiocarbonyl groups, especially the 5-thiourea group, would take the place of 5-acetamide group for the activity. Compound 16, which has 5thiourea moiety, was found to be one of the most potent candidates for the activity.

\section{Experimental}

Melting points were measured with a Yanagimoto melting point apparatus and are uncorrected. Elemental analyses were measured with a Yanagimoto MT-5 elemental analysis apparatus, and were within $\pm 0.4 \%$ of calculated values. ${ }^{1} \mathrm{H}-\mathrm{NMR}$ spectra were measured with a JEOL A-500 $(500 \mathrm{MHz})$ or JEOL JNM-LA300 $(300 \mathrm{MHz})$ spectrometer using tetramethylsilane as an internal standard. Specific optical rotations were measured on a JASCO DIP-370 polarimeter. Column chromatography was carried out with silica gel [Kieselgel 60(Merck)]. TLC was conducted on $0.25 \mathrm{~mm}$ pre-coated silica gel plates $\left(60 \mathrm{~F}_{254}\right.$, Merck). All extracted solvents were dried over $\mathrm{Na}_{2} \mathrm{SO}_{4}$ and the solvent was evaporated in vacuo.

$(S)$-3, 4-Epoxybutenyl Propionate (5) A suspension of (S)-(-)-4-iodo1, 2-epoxybutane ${ }^{13)}(1.00 \mathrm{~g}, 5.05 \mathrm{mmol})$, propionic acid $(0.37 \mathrm{ml}, 5.05$ mmol) and $\mathrm{K}_{2} \mathrm{CO}_{3}(0.90 \mathrm{~g}, 6.51 \mathrm{mmol})$ in methylethylketone $(14 \mathrm{ml})$ was refluxed at $18 \mathrm{~h}$. The mixture was diluted with water and extracted with AcOEt. The extract was washed with brine, dried and concentrated. The residue was purified by column chromatography $\left[\mathrm{SiO}_{2}, n\right.$-Hexane-AcOEt (7: $1 \rightarrow 4: 1)]$ to afford $5(0.21 \mathrm{~g}, 29 \%)$ as colorless oil. $[\alpha]_{\mathrm{D}}^{20}-17.8^{\circ}(c=0.5$, $\left.\mathrm{CH}_{3} \mathrm{Cl}\right) .{ }^{1} \mathrm{H}-\mathrm{NMR}\left(\mathrm{CDCl}_{3}\right) \delta: 1.15(3 \mathrm{H}, \mathrm{t}, J=7.5 \mathrm{~Hz}), 1.80-2.00(2 \mathrm{H}, \mathrm{m})$, $2.35(2 \mathrm{H}, \mathrm{q}, J=7.5 \mathrm{~Hz}), 2.52(1 \mathrm{H}, \mathrm{dd}, J=5,2.5 \mathrm{~Hz}), 2.79(1 \mathrm{H}, \mathrm{t}, J=5 \mathrm{~Hz})$, $3.00-3.05(1 \mathrm{H}, \mathrm{m}), 4.10-4.30(2 \mathrm{H}, \mathrm{m})$.

(S)-3-[3-Fluoro-4-(4-thiomorpholinyl)phenyl]-5-hydroxyethyl oxazolidine-2-one (6) To a solution of $N$-carbobenzoxy-3-fluoro-4-(4-thiomorpholinyl)aniline $\left.{ }^{4}\right)(4)(20.0 \mathrm{~g}, 57.7 \mathrm{mmol})$ in tetrahydrofuran (THF) $(200 \mathrm{ml})$ 
under $\mathrm{N}_{2}$ at $-70{ }^{\circ} \mathrm{C}, n$-BuLi $(37.2 \mathrm{ml}$ of $1.63 \mathrm{~m}$ solution in hexane, 60.6 mmol) was added. After the solution was stirred at the same temperature for $1 \mathrm{~h}, 5(8.74 \mathrm{~g}, 60.6 \mathrm{mmol})$ was added to the reaction mixture. The mixture was then stirred at room temperature for $17 \mathrm{~h}$, saturated aqueous $\mathrm{NH}_{4} \mathrm{Cl}$ was added, and extracted with AcOEt. The extract was washed with brine, dried and concentrated. The residue was purified by column chromatography $\left[\mathrm{SiO}_{2}, \mathrm{CH}_{2} \mathrm{Cl}_{2}-\mathrm{AcOEt}(50: 1 \rightarrow 10: 1 \rightarrow 1: 1)\right]$ to afford $6(3.89 \mathrm{~g}, 21 \%)$ as pale brown crystals. Recrystallization from $\mathrm{MeOH}$ gave pale brown crystals. mp: $132.5-135^{\circ} \mathrm{C}$. $[\alpha]_{\mathrm{D}}^{20}-34.9^{\circ}(c=0.1, \mathrm{DMSO}) .{ }^{1} \mathrm{H}-\mathrm{NMR}\left(\mathrm{CDCl}_{3}\right) \delta$ : $1.65(1 \mathrm{H}, \mathrm{t}, J=5 \mathrm{~Hz}), 1.90-2.15(2 \mathrm{H}, \mathrm{m}), 2.80(4 \mathrm{H}, \mathrm{t}, J=5 \mathrm{~Hz}), 3.29(4 \mathrm{H}, \mathrm{t}$, $J=5 \mathrm{~Hz}), 3.72(1 \mathrm{H}, \mathrm{dd}, J=9,7 \mathrm{~Hz}), 3.85-3.95(2 \mathrm{H}, \mathrm{m}), 4.10(1 \mathrm{H}, \mathrm{t}, J=9$ $\mathrm{Hz}), 4.80-4.90(1 \mathrm{H}, \mathrm{m}), 6.95(1 \mathrm{H}, \mathrm{t}, J=8.5 \mathrm{~Hz}), 7.12(1 \mathrm{H}, \mathrm{dd}, J=8.5,2.5$ $\mathrm{Hz}), 7.40(1 \mathrm{H}$, dd, $J=14,2.5 \mathrm{~Hz})$. Anal. Calcd for $\mathrm{C}_{15} \mathrm{H}_{19} \mathrm{FN}_{2} \mathrm{O}_{3} \mathrm{~S} \cdot 1 / 8 \mathrm{H}_{2} \mathrm{O}$ : C, 54.82; H, 5.90; N, 8.52. Found: C, 54.81; H, 5.89; N, 8.45.

(S)-5-Azidoethyl-3-[3-fluoro-4-(4-thiomorpholinyl)phenyl]oxazolidine2-one (7) To a mixture of $6(3.50 \mathrm{~g}, 10.7 \mathrm{mmol})$ and $\mathrm{Et}_{3} \mathrm{~N}(3.40 \mathrm{ml}, 24.2$ $\mathrm{mmol})$ in $\mathrm{CH}_{2} \mathrm{Cl}_{2}(70 \mathrm{ml})$, methanesulfonyl chloride $(1.00 \mathrm{ml}, 13.1 \mathrm{mmol})$ was added under ice cooling, followed by stirring at room temperature for 1 $\mathrm{h}$. The reaction mixture was washed with water and brine, dried and concentrated to give methanesulfonate. A suspension of the methanesulfonate and sodium azide ( $2.65 \mathrm{~g}, 40.7 \mathrm{mmol}$ ) in $N, N$-dimethylformamide (DMF) (93 ml) was heated at $65^{\circ} \mathrm{C}$ for $6 \mathrm{~h}$. After cooling, the reaction mixture was poured into water and extracted with AcOEt. The extract was washed with brine, dried and concentrated to afford $7(4.69 \mathrm{~g}, 100 \%)$ as pale brown crystals. Recrystallization from $\mathrm{MeOH}$ gave pale brown crystals. $\mathrm{mp}: 101.5-102^{\circ} \mathrm{C}$. $[\alpha]_{\mathrm{D}}^{20}-46.8^{\circ}\left(c=0.1\right.$, DMSO). ${ }^{1} \mathrm{H}-\mathrm{NMR}\left(\mathrm{CDCl}_{3}\right) \delta: 1.95-2.10(2 \mathrm{H}, \mathrm{m})$, $2.80(4 \mathrm{H}, \mathrm{t}, J=5 \mathrm{~Hz}), 3.30(4 \mathrm{H}, \mathrm{t}, J=5 \mathrm{~Hz}), 3.55-3.65(2 \mathrm{H}, \mathrm{m}), 3.65(1 \mathrm{H}$, dd, $J=8.5,6.5 \mathrm{~Hz}), 4.10(1 \mathrm{H}, \mathrm{t}, J=8.5 \mathrm{~Hz}), 4.70-4.80(1 \mathrm{H}, \mathrm{m}), 6.95(1 \mathrm{H}, \mathrm{t}$, $J=8.5 \mathrm{~Hz}), 7.10(1 \mathrm{H}$, dd, $J=8.5,2 \mathrm{~Hz}), 7.40(1 \mathrm{H}, \mathrm{dd}, J=14,2 \mathrm{~Hz})$. Anal. Calcd for $\mathrm{C}_{15} \mathrm{H}_{18} \mathrm{FN}_{5} \mathrm{O}_{2} \mathrm{~S}$ : C, 51.27; H, 5.16; N, 19.93. Found: C, 51.15; H, $4.99 ; \mathrm{N}, 19.63$.

(S)-[[3-[3-Fluoro-4-(4-thiomorpholinyl)phenyl]-2-oxo-5-oxazolidinyl] ethyllacetamide (8) A mixture of $7(4.09 \mathrm{~g}, 11.6 \mathrm{mmol})$ and triphenylphosphine $(3.36 \mathrm{~g}, 12.8 \mathrm{mmol})$ and $\mathrm{H}_{2} \mathrm{O}(4 \mathrm{ml}, 116 \mathrm{mmol})$ in THF $(60 \mathrm{ml})$ was heated at $40^{\circ} \mathrm{C}$ for $17 \mathrm{~h}$. After cooling, the reaction mixture was diluted with dilute hydrochloric acid and extracted with AcOEt. The aqueous layer was made alkaline with aqueous $\mathrm{NaOH}$ and extracted with AcOEt. The extract was washed with water, dried and concentrated to afford pale yellow crystals.

To a solution of the above crystals in pyridine $(10 \mathrm{ml})$, acetic anhydride $(5.50 \mathrm{ml}, 58.2 \mathrm{mmol})$ was added under ice cooling, followed by stirring at room temperature for $1 \mathrm{~h}$. The reaction mixture was evaporated, and then the residue was diluted with dilute hydrochloric acid, and extracted with AcOEt. The extract was washed with brine, dried and concentrated. The residue was washed with AcOEt to afford $\mathbf{8}$ as pale yellow crystals. The physicochemical data are listed in Tables 2 and 3

(R)-[[3-[3-Fluoro-4-(4-thiomorpholinyl)phenyl]-2-oxo-5-oxazolidinyl] methyl]isothiocyanate (11) A mixture of $\mathbf{1 0}^{4)}(5.00 \mathrm{~g}, 16.1 \mathrm{mmol})$, carbon disulfide $(1.00 \mathrm{ml}, 16.1 \mathrm{mmol})$ and $\mathrm{Et}_{3} \mathrm{~N}(2.30 \mathrm{ml}, 16.1 \mathrm{mmol})$ in $\mathrm{THF}(50$ $\mathrm{ml})$ was stirred at room temperature for $5 \mathrm{~h}$. Then ethyl chloroformate $(1.53$ $\mathrm{ml}, 16.1 \mathrm{mmol}$ ) was added to the mixture and stirred at the same temperature for $1 \mathrm{~h}$. The mixture was quenched with water and extracted with AcOEt. The extract was washed with brine, dried and concentrated. The residue was purified by column chromatography $\left[\mathrm{SiO}_{2}, \mathrm{CH}_{2} \mathrm{Cl}_{2}-\mathrm{MeOH}(50: 1)\right]$ to give $11(3.53 \mathrm{~g}, 62 \%)$ as pale yellow crystals. Recrystallization from $\mathrm{CH}_{3} \mathrm{CN}$ gave pale yellow columns. mp: $135.5-136.5^{\circ} \mathrm{C}$. $[\alpha]_{\mathrm{D}}^{20}-151.9^{\circ}(c=0.1$, DMSO). ${ }^{1} \mathrm{H}-\mathrm{NMR}$ (DMSO- $\left.d_{6}\right) \delta: 2.74(4 \mathrm{H}, \mathrm{t}, J=5 \mathrm{~Hz}), 3.22(4 \mathrm{H}, \mathrm{t}, J=5$ $\mathrm{Hz}), 3.79(1 \mathrm{H}, \mathrm{dd}, J=9,5.5 \mathrm{~Hz}), 4.03(1 \mathrm{H}, \mathrm{dd}, J=15.5,5 \mathrm{~Hz}), 4.11(1 \mathrm{H}, \mathrm{dd}$, $J=15.5,3.5 \mathrm{~Hz}), 4.18(1 \mathrm{H}, \mathrm{t}, J=9 \mathrm{~Hz}), 4.90-4.97(1 \mathrm{H}, \mathrm{m}), 7.10(1 \mathrm{H}, \mathrm{t}$, $J=9.5 \mathrm{~Hz}), 7.20(1 \mathrm{H}, \mathrm{dd}, J=9.5,2.5 \mathrm{~Hz}), 7.46(1 \mathrm{H}, \mathrm{dd}, J=14.5,2.5 \mathrm{~Hz})$. Anal. Calcd for $\mathrm{C}_{15} \mathrm{H}_{16} \mathrm{FN}_{3} \mathrm{O}_{2} \mathrm{~S}_{2}: \mathrm{C}, 50.97 ; \mathrm{H}, 4.56 ; \mathrm{N}, 11.89$. Found: $\mathrm{C}$, 51.01; H, 4.60; N, 11.85 .

(S)-3-[3-Fluoro-4-(4-thiomorpholinyl)phenyl]-5-guanidinomethyl oxazolidine-2-one Hydrochloride (12) A mixture of $10(0.30 \mathrm{~g}, 0.963 \mathrm{mmol})$, $N, N$-diisopropylethylamine $(0.25 \mathrm{ml}, 1.45 \mathrm{mmol})$ and $1 H$-pyrazole-1-carboxamidine hydrochloride $(0.21 \mathrm{~g}, 1.45 \mathrm{mmol})$ in DMF $(3 \mathrm{ml})$ was heated at 50 ${ }^{\circ} \mathrm{C}$ for $1.5 \mathrm{~h}$. After cooling, the reaction mixture was diluted with $\mathrm{CH}_{2} \mathrm{Cl}_{2}$. The precipitates were collected by filtration and washed with water to afford 12 as colorless crystals. The physicochemical data are listed in Tables 2 and 3.

(S)- $N$-[[3-[3-Fluoro-4-(4-thiomorpholinyl)phenyl]-2-oxo-5-oxazolidinyl]methyl]thioacetamide (14) A mixture of $2^{4)}(1.58 \mathrm{~g}, 4.47 \mathrm{mmol})$ and Lawesson's reagent $(1.80 \mathrm{~g}, 4.47 \mathrm{mmol})$ in toluene $(20 \mathrm{ml})$ was heated at $90^{\circ} \mathrm{C}$ for $7 \mathrm{~h}$. After the cooling, the reaction mixture was diluted with water,
Table 2. Physical and Analytical Data for 5-Substituted Oxazolidinones

\begin{tabular}{|c|c|c|c|c|c|c|c|}
\hline \multirow{2}{*}{ No. } & \multirow{2}{*}{$\begin{array}{l}\text { Yield } \\
(\%)\end{array}$} & \multirow{2}{*}{$\begin{array}{c}\operatorname{mp}\left({ }^{\circ} \mathrm{C}\right) \\
\text { (Recryst. solv.) }\end{array}$} & \multirow[t]{2}{*}{ Formula } & \multicolumn{3}{|c|}{$\begin{array}{l}\text { Analysis (\%) } \\
\text { Calcd (Found) }\end{array}$} & \multirow{2}{*}{$\begin{array}{c}{[\alpha]_{\mathrm{D}}^{20}} \\
\mathrm{DMSO} \\
(c=0.1)\end{array}$} \\
\hline & & & & $\mathrm{C}$ & $\mathrm{H}$ & $\mathrm{N}$ & \\
\hline 8 & 40 & $\begin{array}{c}169-169.5 \\
(\mathrm{MeOH})\end{array}$ & $\mathrm{C}_{17} \mathrm{H}_{22} \mathrm{FN}_{3} \mathrm{O}_{3} \mathrm{~S}$ & $\begin{array}{r}55.57 \\
(55.44\end{array}$ & $\begin{array}{r}6.03 \\
+6.09\end{array}$ & $\begin{array}{l}11.44 \\
11.42)\end{array}$ & -35.1 \\
\hline 12 & 31 & $\begin{array}{c}258-263 \\
(\mathrm{MeOH})\end{array}$ & $\begin{array}{l}\mathrm{C}_{15} \mathrm{H}_{20} \mathrm{FN}_{5} \mathrm{O}_{2} \mathrm{~S} \\
\cdot \mathrm{HCl}\end{array}$ & $\begin{array}{r}46.05 \\
(46.21\end{array}$ & $\begin{array}{l}5.42 \\
5.43\end{array}$ & $\begin{array}{l}18.21 \\
17.96)\end{array}$ & -51.1 \\
\hline 13 & 44 & $\begin{array}{l}127.5-128 \\
\text { (iso-PrOH) }\end{array}$ & $\mathrm{C}_{15} \mathrm{H}_{18} \mathrm{FN}_{3} \mathrm{O}_{2} \mathrm{~S}_{2}$ & $\begin{array}{r}50.69 \\
(50.50\end{array}$ & $\begin{array}{l}5.10 \\
5.10\end{array}$ & $\begin{array}{l}11.82 \\
11.67)\end{array}$ & +18.9 \\
\hline 14 & 53 & $\begin{array}{c}160-161 \\
(\mathrm{EtOH})\end{array}$ & $\mathrm{C}_{16} \mathrm{H}_{20} \mathrm{FN}_{3} \mathrm{O}_{2} \mathrm{~S}_{2}$ & $\begin{array}{r}52.01 \\
(51.98\end{array}$ & $\begin{array}{l}5.46 \\
5.22\end{array}$ & $\begin{array}{l}11.37 \\
11.37)\end{array}$ & +6.0 \\
\hline 15 & 30 & $\begin{array}{l}158-159 \\
\left(\mathrm{CH}_{3} \mathrm{CN}\right)\end{array}$ & $\mathrm{C}_{17} \mathrm{H}_{22} \mathrm{FN}_{3} \mathrm{O}_{2} \mathrm{~S}_{2}$ & $\begin{array}{r}53.24 \\
(53.16\end{array}$ & $\begin{array}{l}5.78 \\
5.38\end{array}$ & $\begin{array}{l}10.96 \\
11.01)\end{array}$ & +8.0 \\
\hline 16 & 42 & $\begin{array}{c}189.5-190.5 \\
\left(\mathrm{CH}_{3} \mathrm{CN}\right)\end{array}$ & $\mathrm{C}_{15} \mathrm{H}_{19} \mathrm{FN}_{4} \mathrm{O}_{2} \mathrm{~S}_{2}$ & $\begin{array}{r}48.63 \\
(48.63\end{array}$ & $\begin{array}{l}5.17 \\
5.12\end{array}$ & $\begin{array}{l}15.12 \\
15.05)\end{array}$ & -16.9 \\
\hline 17 & 58 & $\begin{array}{c}167.5-170 \\
\left(\mathrm{CH}_{3} \mathrm{CN}\right)\end{array}$ & $\mathrm{C}_{16} \mathrm{H}_{21} \mathrm{FN}_{4} \mathrm{O}_{2} \mathrm{~S}_{2}$ & $\begin{array}{r}49.98 \\
(49.74\end{array}$ & $\begin{array}{l}5.51 \\
5.32\end{array}$ & $\begin{array}{l}14.57 \\
14.47)\end{array}$ & -21.0 \\
\hline 18 & 32 & $\begin{array}{l}155-156 \\
\left(\mathrm{CH}_{3} \mathrm{CN}\right)\end{array}$ & $\mathrm{C}_{17} \mathrm{H}_{23} \mathrm{FN}_{4} \mathrm{O}_{2} \mathrm{~S}_{2}$ & $\begin{array}{r}51.24 \\
(51.22\end{array}$ & $\begin{array}{l}5.82 \\
6.00\end{array}$ & $\begin{array}{l}14.06 \\
14.18)\end{array}$ & -17.0 \\
\hline 19 & 41 & $\begin{array}{c}145-147 \\
(\mathrm{EtOH})\end{array}$ & $\mathrm{C}_{17} \mathrm{H}_{23} \mathrm{FN}_{4} \mathrm{O}_{2} \mathrm{~S}_{2}$ & $\begin{array}{r}51.24 \\
(51.12\end{array}$ & $\begin{array}{l}5.82 \\
5.67\end{array}$ & $\begin{array}{l}14.06 \\
13.89)\end{array}$ & -23.1 \\
\hline 20 & 38 & $\begin{array}{c}191-192 \\
\left(\mathrm{CH}_{2} \mathrm{Cl}_{2}-\mathrm{MeOH}\right)\end{array}$ & $\begin{array}{l}\mathrm{C}_{15} \mathrm{H}_{20} \mathrm{FN}_{5} \mathrm{O}_{2} \mathrm{~S}_{2} \\
\cdot 1 / 4 \mathrm{H}_{2} \mathrm{O}\end{array}$ & $\begin{array}{r}46.20 \\
(46.33\end{array}$ & $\begin{array}{l}5.30 \\
5.17\end{array}$ & $\begin{array}{l}17.96 \\
17.71)\end{array}$ & -27.0 \\
\hline 21 & 50 & $\begin{array}{c}149-150 \\
(\mathrm{EtOH})\end{array}$ & $\mathrm{C}_{17} \mathrm{H}_{23} \mathrm{FN}_{4} \mathrm{O}_{2} \mathrm{~S}_{2}$ & $\begin{array}{r}51.24 \\
(51.28\end{array}$ & $\begin{array}{l}5.82 \\
5.89\end{array}$ & $\begin{array}{l}14.06 \\
13.90)\end{array}$ & -12.0 \\
\hline 22 & 81 & $\begin{array}{c}177.5-178.5 \\
\left(\mathrm{CH}_{3} \mathrm{CN}\right)\end{array}$ & $\mathrm{C}_{15} \mathrm{H}_{18} \mathrm{FN}_{3} \mathrm{O}_{3} \mathrm{~S}$ & $\begin{array}{r}53.08 \\
(53.26\end{array}$ & $\begin{array}{l}5.35 \\
5.12\end{array}$ & $\begin{array}{l}12.38 \\
12.41)\end{array}$ & -29.1 \\
\hline 23 & 85 & $\begin{array}{l}168-169 \\
(\mathrm{AcOEt})\end{array}$ & $\mathrm{C}_{17} \mathrm{H}_{22} \mathrm{FN}_{3} \mathrm{O}_{3} \mathrm{~S}$ & $\begin{array}{r}55.57 \\
(55.70\end{array}$ & $\begin{array}{l}6.03 \\
5.78\end{array}$ & $\begin{array}{l}11.44 \\
11.35)\end{array}$ & -21.0 \\
\hline 24 & 37 & $\begin{array}{c}210-211 \\
\left(\mathrm{CH}_{2} \mathrm{Cl}_{2}-\mathrm{MeOH}\right)\end{array}$ & $\mathrm{C}_{15} \mathrm{H}_{19} \mathrm{FN}_{4} \mathrm{O}_{3} \mathrm{~S}$ & $\begin{array}{r}50.84 \\
(50.99\end{array}$ & $\begin{array}{l}5.40 \\
5.38\end{array}$ & $\begin{array}{l}15.81 \\
15.67)\end{array}$ & -30.0 \\
\hline
\end{tabular}

and extracted with AcOEt. The extract was washed with brine, dried and concentrated. The residue was purified by column chromatography $\left[\mathrm{SiO}_{2}\right.$, AcOEt- $n$-Heptane $(1: 1)]$ to afford $\mathbf{1 4}$ as colorless crystals. The physicochemical data are listed in Tables 2 and 3.

Compounds 13 and 15 were prepared in a similar manner, and their physicochemical data are also listed in Tables 2 and 3.

(S)- $N$-[[3-[3-Fluoro-4-(4-thiomorpholinyl)phenyl]-2-oxo-5-oxazolidinyl]methyl]thiourea (16) A mixture of $11(0.50 \mathrm{~g}, 1.42 \mathrm{mmol})$ and $16 \%$ ammonia in methanol solution $(10 \mathrm{ml})$ in $\mathrm{MeOH}(10 \mathrm{ml})$ was stirred at room temperature for $2 \mathrm{~h}$. The precipitates were collected by filtration and washed with $\mathrm{MeOH}$ to afford $\mathbf{1 6}$ as colorless crystals. The physicochemical data are listed in Tables 2 and 3.

Compound 19 was prepared in a similar manner. The physicochemical data are also listed in Tables 2 and 3.

(S)- $N^{\prime}$-Methyl- $N$-[[3-[3-fluoro-4-(4-thiomorpholinyl)phenyl]-2-oxo-5oxazolidinyl]methyl]thiourea (17) A mixture of $\mathbf{1 0}(9.84 \mathrm{~g}, 16.0 \mathrm{mmol})$, $\mathrm{Et}_{3} \mathrm{~N}(5.00 \mathrm{ml}, 35.9 \mathrm{mmol})$ and methyl isothiocyanate $(2.30 \mathrm{ml}, 32.0 \mathrm{mmol})$ in $\mathrm{CH}_{2} \mathrm{Cl}_{2}(100 \mathrm{ml})$ was stirred at room temperature for $18 \mathrm{~h}$. The mixture was washed with water, dried and concentrated. The residue was purified by column chromatography $\left[\mathrm{SiO}_{2}, \mathrm{CH}_{2} \mathrm{Cl}_{2}-\mathrm{MeOH}(30: 1)\right]$ to give 17 as colorless crystals. The physicochemical data are listed in Tables 2 and 3.

Compound 18 was prepared in a similar manner. The physicochemical data are listed in Tables 2 and 3.

(S)-4-[[3-[3-Fluoro-4-(4-thiomorpholinyl)phenyl]-2-oxo-5-oxazolidinyl|methyl]thiosemicarbazide (20) A mixture of $\mathbf{1 0}(0.30 \mathrm{~g}, 0.963$ $\mathrm{mmol})$ and 4-methyl-4-phenyl-3-thiosemicarbazide $(0.26 \mathrm{~g}, 1.44 \mathrm{mmol})$ in DMF $(1 \mathrm{ml})$ was heated at $90{ }^{\circ} \mathrm{C}$ for $7 \mathrm{~h}$. The reaction mixture was diluted with water. The precipitates were collected by filtration, and purified by column chromatography $\left[\mathrm{SiO}_{2}, \mathrm{CH}_{2} \mathrm{Cl}_{2}-\mathrm{MeOH}(50: 1)\right]$ to give 20 as brown crystals. The physicochemical data are listed in Tables 2 and 3.

$(S)-N, N^{\prime}$-Dimethyl- $N$-[[3-[3-fluoro-4-(4-thiomorpholinyl)phenyl]-2oxo-5-oxazolidinyl]methyl]thiourea (21) A mixture of $\mathbf{9}^{4)}(1.00 \mathrm{~g}, 2.67$ $\mathrm{mmol}), \mathrm{MeOH}(10 \mathrm{ml})$ and $40 \%$ methylamine in methanol solution $(6 \mathrm{ml})$ was refluxed for $72 \mathrm{~h}$. The mixture was concentrated, and then the residue was treated with $\mathrm{Et}_{3} \mathrm{~N}(0.80 \mathrm{ml}, 5.63 \mathrm{mmol})$ and methyl isothiocyanate $(0.70$ $\mathrm{ml}, 7.47 \mathrm{mmol})$ in $\mathrm{CH}_{2} \mathrm{Cl}_{2}(16 \mathrm{ml})$ at room temperature and stirred for $2.5 \mathrm{~h}$. 
Table 3. Spectral Data for 5-Substituted Oxazolidinones

No. $\quad{ }^{1} \mathrm{H}-\mathrm{NMR}\left(\right.$ in DMSO- $\left.d_{6}\right) \delta(\mathrm{ppm})$

8

12

13

14

15

16

17

18

19

20

21

22

23

24

$1.81(3 \mathrm{H}, \mathrm{s}), 1.80-1.90(2 \mathrm{H}, \mathrm{m}), 2.74(4 \mathrm{H}, \mathrm{t}, J=5 \mathrm{~Hz}), 3.10-3.25(2 \mathrm{H}, \mathrm{m}), 3.22(4 \mathrm{H}, \mathrm{t}, J=5 \mathrm{~Hz}), 3.69(1 \mathrm{H}, \mathrm{dd}, J=9,8.5 \mathrm{~Hz}), 4.11$ $(1 \mathrm{H}, \mathrm{t}, J=9 \mathrm{~Hz}), 4.60-4.70(1 \mathrm{H}, \mathrm{m}), 7.09(1 \mathrm{H}, \mathrm{t}, J=9 \mathrm{~Hz}), 7.19(1 \mathrm{H}, \mathrm{dd}, J=9,2.5 \mathrm{~Hz}), 7.46(1 \mathrm{H}, \mathrm{dd}, J=14.5,2.5 \mathrm{~Hz}), 7.83(1 \mathrm{H}, \mathrm{brs})$ $2.65-2.80(4 \mathrm{H}, \mathrm{m}), 3.17-3.30(4 \mathrm{H}, \mathrm{m}), 3.53(1 \mathrm{H}, \mathrm{dd}, J=15,6.5 \mathrm{~Hz}), 3.62(1 \mathrm{H}, \mathrm{dd}, J=15,3.5 \mathrm{~Hz}), 3.73(1 \mathrm{H}, \mathrm{dd}, J=9,6 \mathrm{~Hz}), 4.12$ $(1 \mathrm{H}, \mathrm{t}, J=9 \mathrm{~Hz}), 4.75-4.83(1 \mathrm{H}, \mathrm{m}), 7.10(1 \mathrm{H}, \mathrm{t}, J=8.5 \mathrm{~Hz}), 7.19(1 \mathrm{H}, \mathrm{dd}, J=8.5,2 \mathrm{~Hz}), 7.37(3 \mathrm{H}, \mathrm{br} \mathrm{s}), 7.47(1 \mathrm{H}, \mathrm{dd}, J=14.5,2 \mathrm{~Hz})$, $8.07(1 \mathrm{H}$, br s $)$ $2.74(4 \mathrm{H}, \mathrm{t}, J=5.5 \mathrm{~Hz}), 3.22(4 \mathrm{H}, \mathrm{t}, J=5.5 \mathrm{~Hz}), 3.79(1 \mathrm{H}, \mathrm{dd}, J=9,6.5 \mathrm{~Hz}), 3.96(2 \mathrm{H}, \mathrm{t}, J=5.5 \mathrm{~Hz}), 4.13(1 \mathrm{H}, \mathrm{t}, J=9 \mathrm{~Hz}), 4.90-5.00$ $(1 \mathrm{H}, \mathrm{m}), 7.09(1 \mathrm{H}, \mathrm{t}, J=9 \mathrm{~Hz}), 7.17(1 \mathrm{H}, \mathrm{dd}, J=9,2.5 \mathrm{~Hz}), 7.45(1 \mathrm{H}, \mathrm{dd}, J=14.5,2.5 \mathrm{~Hz}), 9.36(1 \mathrm{H}, \mathrm{d}, J=5.5 \mathrm{~Hz}), 10.5(1 \mathrm{H}, \mathrm{brs})$ $2.44(3 \mathrm{H}, \mathrm{s}), 2.74(4 \mathrm{H}, \mathrm{t}, J=4.5 \mathrm{~Hz}), 3.22(4 \mathrm{H}, \mathrm{t}, J=4.5 \mathrm{~Hz}), 3.80(1 \mathrm{H}, \mathrm{t}, J=8 \mathrm{~Hz}), 3.85-3.95(2 \mathrm{H}, \mathrm{m}), 4.12(1 \mathrm{H}, \mathrm{t}, J=9 \mathrm{~Hz}), 4.90-$ $5.00(1 \mathrm{H}, \mathrm{m}), 7.09(1 \mathrm{H}, \mathrm{t}, J=9 \mathrm{~Hz}), 7.19(1 \mathrm{H}, \mathrm{dd}, J=9,1 \mathrm{~Hz}), 7.45(1 \mathrm{H}, \mathrm{dd}, J=14.5,1 \mathrm{~Hz}), 10.2(1 \mathrm{H}, \mathrm{brs})$

$1.15(3 \mathrm{H}, \mathrm{t}, J=7.5 \mathrm{~Hz}), 2.59(2 \mathrm{H}, \mathrm{q}, J=7.5 \mathrm{~Hz}), 2.74(4 \mathrm{H}, \mathrm{t}, J=5 \mathrm{~Hz}), 3.20(4 \mathrm{H}, \mathrm{t}, J=5 \mathrm{~Hz}), 3.80(1 \mathrm{H}, \mathrm{dd}, J=9,6 \mathrm{~Hz}), 3.85-4.00(2 \mathrm{H}$, m), $4.12(1 \mathrm{H}, \mathrm{t}, J=9 \mathrm{~Hz}), 4.90-5.00(1 \mathrm{H}, \mathrm{m}), 7.09(1 \mathrm{H}, \mathrm{t}, J=9 \mathrm{~Hz}), 7.17(1 \mathrm{H}, \mathrm{dd}, J=9,2.5 \mathrm{~Hz}), 7.45(1 \mathrm{H}, \mathrm{dd}, J=14.5,2.5 \mathrm{~Hz}), 10.2$ $(1 \mathrm{H}, \mathrm{br} \mathrm{s})$

$2.74(4 \mathrm{H}, \mathrm{t}, J=5 \mathrm{~Hz}), 3.22(4 \mathrm{H}, \mathrm{t}, J=5 \mathrm{~Hz}), 3.70-3.85(3 \mathrm{H}, \mathrm{m}), 4.08(1 \mathrm{H}, \mathrm{t}, J=9 \mathrm{~Hz}), 4.78-4.84(1 \mathrm{H}, \mathrm{m}), 7.09(1 \mathrm{H}, \mathrm{t}, J=9 \mathrm{~Hz}), 7.18$ $(1 \mathrm{H}, \mathrm{dd}, J=9,2.5 \mathrm{~Hz}), 7.19(2 \mathrm{H}, \mathrm{brs}), 7.46(1 \mathrm{H}, \mathrm{dd}, J=14.5,2.5 \mathrm{~Hz}), 7.84(1 \mathrm{H}, \mathrm{t}, J=6 \mathrm{~Hz})$

$2.74(4 \mathrm{H}, \mathrm{t}, J=5 \mathrm{~Hz}), 2.84(3 \mathrm{H}, \mathrm{brs}), 3.22(4 \mathrm{H}, \mathrm{t}, J=5 \mathrm{~Hz}), 3.75-3.85(3 \mathrm{H}, \mathrm{m}), 4.08(1 \mathrm{H}, \mathrm{t}, J=9 \mathrm{~Hz}), 4.81-4.90(1 \mathrm{H}, \mathrm{m}), 7.09(1 \mathrm{H}, \mathrm{t}$, $J=8.5 \mathrm{~Hz}), 7.17(1 \mathrm{H}, \mathrm{dd}, J=8.5,2.5 \mathrm{~Hz}), 7.45(1 \mathrm{H}, \mathrm{dd}, J=14.5,2.5 \mathrm{~Hz}), 7.52(1 \mathrm{H}, \mathrm{brs}), 7.65(1 \mathrm{H}, \mathrm{t}, J=6 \mathrm{~Hz})$

$1.05(3 \mathrm{H}, \mathrm{t}, J=7 \mathrm{~Hz}), 2.73(4 \mathrm{H}, \mathrm{t}, J=5 \mathrm{~Hz}), 3.22(4 \mathrm{H}, \mathrm{t}, J=5 \mathrm{~Hz}), 3.38(2 \mathrm{H}, \mathrm{brs}), 3.80-3.85(3 \mathrm{H}, \mathrm{m}), 4.08(1 \mathrm{H}, \mathrm{t}, J=9 \mathrm{~Hz}), 4.81-4.87$ $(1 \mathrm{H}, \mathrm{m}), 7.09(1 \mathrm{H}, \mathrm{t}, J=9 \mathrm{~Hz}), 7.18(1 \mathrm{H}, \mathrm{dd}, J=9,2 \mathrm{~Hz}), 7.45(1 \mathrm{H}, \mathrm{dd}, J=14.5,2 \mathrm{~Hz}), 7.52(1 \mathrm{H}, \mathrm{brs}), 7.56(1 \mathrm{H}, \mathrm{t}, J=5.5 \mathrm{~Hz})$

$2.74(4 \mathrm{H}, \mathrm{t}, J=5 \mathrm{~Hz}), 3.16(6 \mathrm{H}, \mathrm{s}), 3.20(4 \mathrm{H}, \mathrm{t}, J=5 \mathrm{~Hz}), 3.76-4.10(3 \mathrm{H}, \mathrm{m}), 4.20(1 \mathrm{H}, \mathrm{t}, J=9 \mathrm{~Hz}), 4.85-4.95(1 \mathrm{H}, \mathrm{m}), 7.10(1 \mathrm{H}, \mathrm{t}$, $J=8.5 \mathrm{~Hz}), 7.20(1 \mathrm{H}, \mathrm{dd}, J=8.5,2.5 \mathrm{~Hz}), 7.45(1 \mathrm{H}, \mathrm{dd}, J=14.5,2.5 \mathrm{~Hz}), 7.57(1 \mathrm{H}, \mathrm{t}, J=5.5 \mathrm{~Hz})$

$2.65-2.80(4 \mathrm{H}, \mathrm{m}), 3.10-3.30(4 \mathrm{H}, \mathrm{m}), 3.86(2 \mathrm{H}, \mathrm{brs}), 3.90(1 \mathrm{H}, \mathrm{dd}, J=9,6 \mathrm{~Hz}), 4.07(1 \mathrm{H}, \mathrm{t}, J=9 \mathrm{~Hz}), 4.48(2 \mathrm{H}, \mathrm{brs}), 4.80-4.90$ $(1 \mathrm{H}, \mathrm{m}), 7.09(1 \mathrm{H}, \mathrm{t}, J=9 \mathrm{~Hz}), 7.18(1 \mathrm{H}, \mathrm{dd}, J=9,2.5 \mathrm{~Hz}), 7.45(1 \mathrm{H}, \mathrm{dd}, J=14.5,2.5 \mathrm{~Hz}), 8.00(1 \mathrm{H}, \mathrm{brs}), 8.76(1 \mathrm{H}, \mathrm{brs})$

$2.74(4 \mathrm{H}, \mathrm{t}, J=5 \mathrm{~Hz}), 2.93(3 \mathrm{H}, \mathrm{d}, J=4.5 \mathrm{~Hz}), 3.13(3 \mathrm{H}, \mathrm{s}), 3.22(4 \mathrm{H}, \mathrm{t}, J=5 \mathrm{~Hz}), 3.82(1 \mathrm{H}, \mathrm{t}, J=9 \mathrm{~Hz}), 3.99(1 \mathrm{H}, \mathrm{dd}, J=14.5,9 \mathrm{~Hz})$, $4.08(1 \mathrm{H}, \mathrm{t}, J=9 \mathrm{~Hz}), 4.32(1 \mathrm{H}, \mathrm{dd}, J=14.5,3.5 \mathrm{~Hz}), 4.90-4.98(1 \mathrm{H}, \mathrm{m}), 7.09(1 \mathrm{H}, \mathrm{t}, J=9 \mathrm{~Hz}), 7.19(1 \mathrm{H}, \mathrm{dd}, J=9,2.5 \mathrm{~Hz}), 7.45(1 \mathrm{H}$, dd, $J=14.5,2.5 \mathrm{~Hz}), 7.51(1 \mathrm{H}, \mathrm{d}, J=4.5 \mathrm{~Hz})$

$2.74(4 \mathrm{H}, \mathrm{t}, J=5 \mathrm{~Hz}), 3.22(4 \mathrm{H}, \mathrm{t} J=5 \mathrm{~Hz}), 3.47(2 \mathrm{H}, \mathrm{t}, J=5.5 \mathrm{~Hz}), 3.72(1 \mathrm{H}, \mathrm{dd}, J=9,6 \mathrm{~Hz}), 4.09(1 \mathrm{H}, \mathrm{t}, J=9 \mathrm{~Hz}), 4.70-4.80(1 \mathrm{H}, \mathrm{m})$, $7.09(1 \mathrm{H}, \mathrm{t}, J=9 \mathrm{~Hz}), 7.17(1 \mathrm{H}, \mathrm{dd}, J=9,2.5 \mathrm{~Hz}), 7.45(1 \mathrm{H}, \mathrm{dd}, J=14.5,2.5 \mathrm{~Hz}), 8.09(1 \mathrm{H}, \mathrm{brs}), 8.27(1 \mathrm{H}, \mathrm{brs})$

$0.97(3 \mathrm{H}, \mathrm{t}, J=7.5 \mathrm{~Hz}), 2.10(2 \mathrm{H}, \mathrm{q}, J=7.5 \mathrm{~Hz}), 2.74(4 \mathrm{H}, \mathrm{t}, J=5 \mathrm{~Hz}), 3.22(4 \mathrm{H}, \mathrm{t}, J=5 \mathrm{~Hz}), 3.35-3.45(2 \mathrm{H}, \mathrm{m}), 3.71(1 \mathrm{H}, \mathrm{dd}, J=9,6$ $\mathrm{Hz}), 4.07(1 \mathrm{H}, \mathrm{t}, J=9 \mathrm{~Hz}), 4.65-4.75(1 \mathrm{H}, \mathrm{m}), 7.09(1 \mathrm{H}, \mathrm{t}, J=9 \mathrm{~Hz}), 7.16(1 \mathrm{H}, \mathrm{dd}, J=9,2.5 \mathrm{~Hz}), 7.44(1 \mathrm{H}, \mathrm{dd}, J=14.5,2.5 \mathrm{~Hz}), 8.02$ $(1 \mathrm{H}, \mathrm{t}, J=5.5 \mathrm{~Hz})$

$2.70-2.80(4 \mathrm{H}, \mathrm{m}), 3.20-3.30(4 \mathrm{H}, \mathrm{m}), 3.34(2 \mathrm{H}, \mathrm{t}, J=5.5 \mathrm{~Hz}), 3.72(1 \mathrm{H}, \mathrm{dd}, J=9,6.5 \mathrm{~Hz}), 4.06(1 \mathrm{H}, \mathrm{t}, J=9 \mathrm{~Hz}), 4.65-4.70(1 \mathrm{H}$, $\mathrm{m}), 5.48(2 \mathrm{H}, \mathrm{brs}), 6.24(1 \mathrm{H}, \mathrm{t}, J=6 \mathrm{~Hz}), 7.08(1 \mathrm{H}, \mathrm{t}, J=9 \mathrm{~Hz}), 7.17(1 \mathrm{H}, \mathrm{dd}, J=9,2.5 \mathrm{~Hz}), 7.46(1 \mathrm{H}, \mathrm{dd}, J=14.5,2.5 \mathrm{~Hz})$

The reaction mixture was washed with water, dried and concentrated to afford $\mathbf{2 1}$ as pale yellow crystals. The physicochemical data are listed in Tables 2 and 3 .

(S)-N-[[3-[3-Fluoro-4-(4-thiomorpholinyl)phenyl]-2-oxo-5-oxazolidinyl]methyl|formamide (22) A mixture of $\mathbf{1 0}(1.00 \mathrm{~g}, 3.21 \mathrm{mmol})$ and ethyl formate $(3.00 \mathrm{ml}, 38.5 \mathrm{mmol})$ in EtOH $(10 \mathrm{ml})$ was refluxed for $17 \mathrm{~h}$. After cooling, the reaction mixture was concentrated. The residue was washed with EtOH to afford 22 as colorless crystals. The physicochemical data of compound 22 are listed in Tables 2 and 3.

(S)- $N$-[[3-[3-Fluoro-4-(4-thiomorpholinyl)phenyl]-2-oxo-5-oxazolidinyl]methyl]propionamide (23) To a mixture of $\mathbf{1 0}(1.00 \mathrm{~g}, 3.21 \mathrm{mmol})$ and $\mathrm{Et}_{3} \mathrm{~N}(0.49 \mathrm{ml}, 3.53 \mathrm{mmol})$ in THF $(10 \mathrm{ml})$, propionyl chloride $(0.31 \mathrm{ml}$, $3.53 \mathrm{mmol}$ ) was added under ice cooling, followed by stirring at the same temperature for $5 \mathrm{~h}$. Then the reaction mixture was washed with water and extracted with AcOEt. The extract was dried and concentrated to afford 23 as pale brown crystals. The physicochemical data are listed in Tables 2 and 3.

(S)- $N$-[[3-[3-Fluoro-4-(4-thiomorpholinyl)phenyl]-2-oxo-5-oxazolidinyl] methyl]urea (24) A mixture of $10(0.30 \mathrm{~g}, 0.963 \mathrm{mmol})$ and sodium cyanate $(0.22 \mathrm{~g}, 2.89 \mathrm{mmol})$ in acetic acid-water $1: 1(2.4 \mathrm{ml})$ was stirred at room temperature for $4 \mathrm{~h}$. The reaction mixture was evaporated, and the residue was washed with water to afford $\mathbf{2 4}$ as colorless crystals. The physicochemical data of compound $\mathbf{2 4}$ are listed in Tables 2 and 3.

In Vitro Studies These studies were conducted according to the method of the Japan Society of Chemotherapy. ${ }^{14)}$ The minimum inhibitory concentrations (MICs, $\mu \mathrm{g} / \mathrm{ml}$ ) were determined by an agar dilution method with Muller-Hinton agar (MHA, Difco Laboratories, Detroit, Mich). Bacterial suspensions for inocula were prepared by diluting overnight cultures of organisms to give a final concentration of $10^{6} \mathrm{CFU} / \mathrm{ml}$, and one loopful $(5 \mu \mathrm{l})$ of an inoculum, corresponding to about $5 \times 10^{3} \mathrm{CFU}$ per spot was inoculated on drug-containing agar plates. The plates were incubated for $18-24 \mathrm{~h}$ at 37 ${ }^{\circ} \mathrm{C}$. The MIC was defined as the lowest drug concentration that prevented visible growth of bacteria.

\section{References and Notes}

1) Gregory W. A., Brittelli D. R., Wang C.-L. J., Wuonola M. A., McRipley R. J., Eustice D. C., Eberly V. S., Bartholomew P. T., Slee A. M., Forbes M., J. Med. Chem., 32, 1673-1681 (1989).

2) Slee A. M., Wuonola M. A., McRipley R. J., Zajac I., Zawada M. J., Bartholomew P. T., Gregory W. A., Forbes M., Antimicrob. Agents Chemother., 31, 1791-1797 (1987); Barry A. L., ibid., 32, 150-152 (1988); Neu H.C., Novelli A., Saha G., Chin N.-X., ibid., 32, 580583 (1988).

3) Eustice D. C., Feldman P.A., Zajac I., Slee A. M., Antimicrob. Agents. Chemother., 32, 1218-1222 (1988).

4) Barbachyn M. R., Brickner S. J., Hutchinson D. K., World Intellectual Property Organization 9507271 (1995) [Chem. Abstr., 123, $256742 f$ (1995)]; Barbachyn M. R., Hutchinson D. K., Brickner S. J., Cynamon M. H., Kilburn J. O., Klemens S. P., Glickman S. E., Grega K. C., Hendges S. K., Toops D. S., Ford C. W., Zurenko G. E., J. Med. Chem., 39, 680-685 (1996).

5) a) Brickner S. J., Hutchinson D. K., Barbachyn M. R., Garmon S. A., Grega K. C., Hendges S. K., Manninen P. R., Toops D. S., Ulanowicz D. A., Kilburn J. O., Glickman S., Zurenko G. E., Ford C. W., 35th Interscience Conference on Antimicrobial Agents and Chemotherapy, San Francisco, September, 1995, abstract No. F 208, p. 149; b) Brickner S. J., Hutchinson D. K., Barbachyn M. R., Manninen P. R., Ulanowicz D. A., Garmon S. A., Grega K. C., Hendges S. K., Toops D. S., Ford C. W., Zurenko G. E., J. Med. Chem., 39, 673-679 (1996).

6) Lin A. H., Murray R. W., Vidmar T. J., Marotti K. R., Antimicrob. Agents Chemother., 41, 2127-2131 (1997); Shinabarger D. L., Marotti K. R, Murray R. W, Lin A. H, Melchior E. P, Swaney S. M, Dunyak D. S, Demyan W. F, Buysse J. M., ibid., 41, 2132-2136 (1997).

7) Fugitt R. B., Luckenbaugh R. W., European Patent 50827 (1982) [Chem. Abstr., 97, 109990b. (1982)]; Gregory W. A., European Patent 81200 (1984) [Chem. Abstr., 100, 51564c (1984)].

8) a) Riedl B., Haebich D., Stolle A., Ruppelt M., Bartel S. Guarrieri W., Endermann R., Kroll H-P., Ger. Offen. Patent 19601264 (1997) 
[Chem. Abstr., 127, 149139a (1997)]; b) Haebich D., Stolle A., Riedl B., Ruppelt M., Bartel S., Guarnieri W., Endermann R., Kroll H-P., Ger. Offen. Patent 19601265 (1997) [Chem. Abstr., 127, 149138z (1997)]; c) Riedl B., Haebich D., Stolle A., Ruppelt M., Bartel S., Guarnieri W., Endermann R., Kroll H-P., Ger. Offen. Patent 19604223 (1997) [Chem. Abstr., 127, 205567c (1997)]; d) Hester J. B., Nidy E. G., Perricone S. C., Poel T- J., World Intellectual Property Organization 9854161 (1998) [Chem. Abstr., 130, 38373q (1999)]; e) Thomasco L. M., Gadwood R. C., Anderson D. J., World Intellectual Property Organization 9902525 (1999) [Chem. Abstr., 130, 139334h (1999)]; $f$ ) Hester J. B., World Intellectual Property Organization 9924428 (1999) [Chem. Abstr., 130, 338127t (1999)].

9) Calculated $\log P$ values were measured by ACD/Labs $\log P$ calculated., ver. 3.0 (Advanced Chemistry Development, Inc.)

10) Some 5-thiocarbonyl oxazolidinones were reported at the same time that we synthesized them: see ref. $8 d$ ).

11) Denis A., Villette T., Bioorganic \& Medicinal Chemistry Letters, 4, 1925-1930 (1994); Seneci P., Caspani M., Ripamonti F., Ciabatti R., J. Chem. Soc., Perkin. Trans. 1, 1994, 2345-2351.

12) Vidaluc J-L., Calmel F., Bigg D., Carilla E., Stenger A., Chopin P., Briley M., J. Med. Chem., 37, 689-695 (1994); Bell F. W., Cantrell A. S., Högberg M., Jaskunas. S. R., Johansson N. G., Jordan C. L., Kinnick M. D., Lind P., Morin J. M., Jr., Noréen R., Öberg B., Palkowitz J. A., Parrish C. A., Pranc P., Sahlberg C., Ternansky R. J., Vasileff R. T., Vrang L., West S. J., Zhang H., Zhou X-X., J. Med. Chem., 38, 49294936 (1995)

13) Boger D. L., Panek J. S., J. Org. Chem., 46, 1208-1210 (1981)

14) Goto S., Jo K., Kawakita T., Kosakai N., Mitsuhashi S., Nishino T., Ohsawa N., Tanami H., Chemotherapy, 29, 76-79 (1981). 